\title{
Maribius salinus gen. nov., sp. nov., isolated from a solar saltern and Maribius pelagius sp. nov., cultured from the Sargasso Sea, belonging to the Roseobacter clade
}

Correspondence Byung C. Cho bccho@snu.ac.kr

\author{
Dong H. Choi, ${ }^{1} \dagger \ddagger$ Jang-Cheon Cho, ${ }^{2} \dagger$ Brian D. Lanoil, ${ }^{3}$ \\ Stephen J. Giovannoni ${ }^{4}$ and Byung C. Cho ${ }^{1}$
}

\begin{abstract}
${ }^{1}$ School of Earth and Environmental Sciences and Research Institute of Oceanography, Seoul National University, Seoul 151-742, Republic of Korea

${ }^{2}$ Division of Life and Marine Sciences, Inha University, Incheon 402-751, Republic of Korea

${ }^{3}$ Department of Environmental Sciences, University of California, Riverside, CA 92521, USA

${ }^{4}$ Department of Microbiology, Oregon State University, Corvallis, OR 97331, USA
\end{abstract}

\begin{abstract}
Two strictly aerobic, Gram-negative bacteria, designated strains CL-SP27 ${ }^{\top}$ and B5-6 ${ }^{\top}$, were isolated from the hypersaline water of a solar saltern in Korea and from the surface water of the Sargasso Sea, respectively. The two strains were rod-shaped, non-motile and grew on marine agar 2216 as beige colonies. Phylogenetic analyses of 16S rRNA gene sequences revealed a clear affiliation of the novel strains to the family Rhodobacteraceae. However, the novel strains were only distantly related to members of the Roseobacter clade, forming a distinct lineage. Although the $16 \mathrm{~S}$ rRNA gene sequence similarity between strains CL-SP27 ${ }^{\top}$ and B5-6 ${ }^{\top}$ was very high (99.6\%), DNA-DNA relatedness between the strains was $48.4 \%$, suggesting that the strains be categorized as two genospecies. Additionally, the two novel strains could be differentiated by DNA G $+\mathrm{C}$ contents, fatty acid profiles, carbon source utilization patterns, antibiotic susceptibilities and biochemical characteristics. Based on taxonomic data obtained in this study, strains CL-SP27 $7^{\top}$ and B5- $6^{\top}$ represent separate species within a novel genus of the family Rhodobacteraceae, for which the names Maribius salinus gen. nov., sp. nov. (type species) and Maribius pelagius sp. nov. are proposed. The type strains of Maribius salinus and Maribius pelagius are CL-SP27 ${ }^{\top}(=\mathrm{KCCM}$ $\left.42113^{\top}=\mathrm{JCM} 13037^{\top}\right)$ and B5-6 $6^{\top}\left(=\mathrm{KCCM} 42336^{\top}=\mathrm{JCM} 14009^{\top}\right)$, respectively.
\end{abstract}

Since the first description of a bacterium belonging to the Roseobacter clade within the $\alpha-3$ subgroup of the phylum Proteobacteria (Shiba, 1991), many novel species in the Roseobacter clade have been isolated from various marine environments (seawater, sediment, marine algae, invertebrates, vertebrates, hypersaline microbial mats and coastal

tThese authors contributed equally to this work.

¥Present address: Marine Environmental Research Department, Korea Ocean Research and Development Institute (KORDI), Ansan 426-744, Republic of Korea.

Abbreviation: $\mathrm{PHB}$, poly $\beta$-hydroxybutyrate.

The GenBank/EMBL/DDBJ accession numbers for the 16S rRNA gene sequences of strain CL-SP27 ${ }^{\top}$ and $B 5-6^{\top}$ are AY906863 and DQ514326, respectively.

A table giving the major characteristics that differentiate strains $\mathrm{CL}$ $\mathrm{SP} 27^{\top}$ and $\mathrm{B} 5-6^{\top}$ from other related members of the family Rhodobacteraceae is available as supplementary material in IJSEM Online. biofilms). Nowadays, the Roseobacter clade within the family Rhodobacteraceae is known to be one of the most abundant groups in marine environments (Giovannoni \& Rappé, 2000; Selje et al., 2004; Buchan et al., 2005). Members of the Roseobacter clade show diverse physiological and morphological features (e.g. phototrophy, aerobic sulfite oxidation, organic sulfur compound degradation, methylotrophy, gas vacuoles, poly $\beta$-hydroxybutyrate granules, rosette formation) (Arahal et al., 2005; Buchan et al., 2005). In this study, two strains, designated CL-SP2 $7^{\mathrm{T}}$ and $\mathrm{B} 5-6^{\mathrm{T}}$, were isolated from hypersaline water of a solar saltern in Korea and surface seawater from the Sargasso Sea, Atlantic Ocean. Although the two novel strains were isolated from different geographical origins, the $16 \mathrm{~S}$ rRNA gene sequences of the strains were $99.6 \%$ similar. A polyphasic taxonomic approach was used to determine whether the two novel strains represent the same or separate species. Based on these data, it is proposed that the isolates represent two novel species in a new genus within the family Rhodobacteraceae. 
Strain CL-SP27 ${ }^{\mathrm{T}}$ was isolated from a hypersaline water sample ( $31.8 \%$ salinity) from a solar saltern in Seosin, Korea, using a standard dilution plating method on marine agar 2216 (MA, Difco) plates. After incubation of the plates at $30^{\circ} \mathrm{C}$ for 2 weeks, strain CL-SP $27^{\mathrm{T}}$ was purified as single colonies. Strain B5-6 $6^{\mathrm{T}}$ was isolated from a surface $(5 \mathrm{~m})$ seawater sample from the western Sargasso Sea on R2A seawater agar medium (Lanoil et al., 2000) and routinely maintained on MA at $30^{\circ} \mathrm{C}$.

Nearly complete $16 \mathrm{~S}$ rRNA gene sequences for strains CLSP $27^{\mathrm{T}}$ (1385 bp) and B5-6 ${ }^{\mathrm{T}}$ (1405 bp) were obtained as described previously (Cho \& Giovannoni, 2003; Choi et al., 2006) and used for phylogenetic analyses. The 16S rRNA gene sequences were aligned with those of members of the family Rhodobacteraceae using the jPHYDIT program (Jeon et al., 2005). Phylogenetic trees were generated by neighbour-joining (Saitou \& Nei, 1987) with the Jukes \& Cantor model (1969), maximum-parsimony (Fitch, 1971) and maximum-likelihood (Felsenstein, 1981) methods, using MEGA3 (Kumar et al., 2004) and PAUP 4.0 (Swofford, 1998). The robustness of the tree topologies was assessed by bootstrap analyses based on 1000 replications for the neighbour-joining and maximum-parsimony trees and 100 replications for the maximum-likelihood tree. Likelihood parameters were estimated by the hierarchical ratio tests in MODELTEST, version 3.04 (Posada \& Crandall, 1998). The 16S rRNA gene sequence similarity between strains CL-SP27 $7^{\mathrm{T}}$ and B5-6 ${ }^{\mathrm{T}}$ was $99.6 \%$. Phylogenetic analyses based on the 16S rRNA gene sequences as well as BLASTN search (Altschul et al., 1990) results showed that strains CL-SP27 $7^{\mathrm{T}}$ and B5-6 ${ }^{\mathrm{T}}$ belong to the Roseobacter clade within the family Rhodobacteraceae. The novel strains showed 93.0-93.2\% gene sequence similarity to Jannaschia helgolandensis and Oceanicola granulosus and 90.4-92.9\% to various type species belonging to the Roseobacter clade. In the phylogenetic trees generated by the three phylogenetic reconstruction methods, the novel strains formed a distinct clade within the family Rhodobacteraceae, but were not specifically associated with any species in the family (Fig. 1). Phylogenetic analyses and the low levels of $16 \mathrm{~S}$ rRNA gene sequence similarities between the novel strains and other members of the family Rhodobacteraceae clade indicate that strains CL-SP27 $7^{\mathrm{T}}$ and B5- $6^{\mathrm{T}}$ represent a new genus in the family.

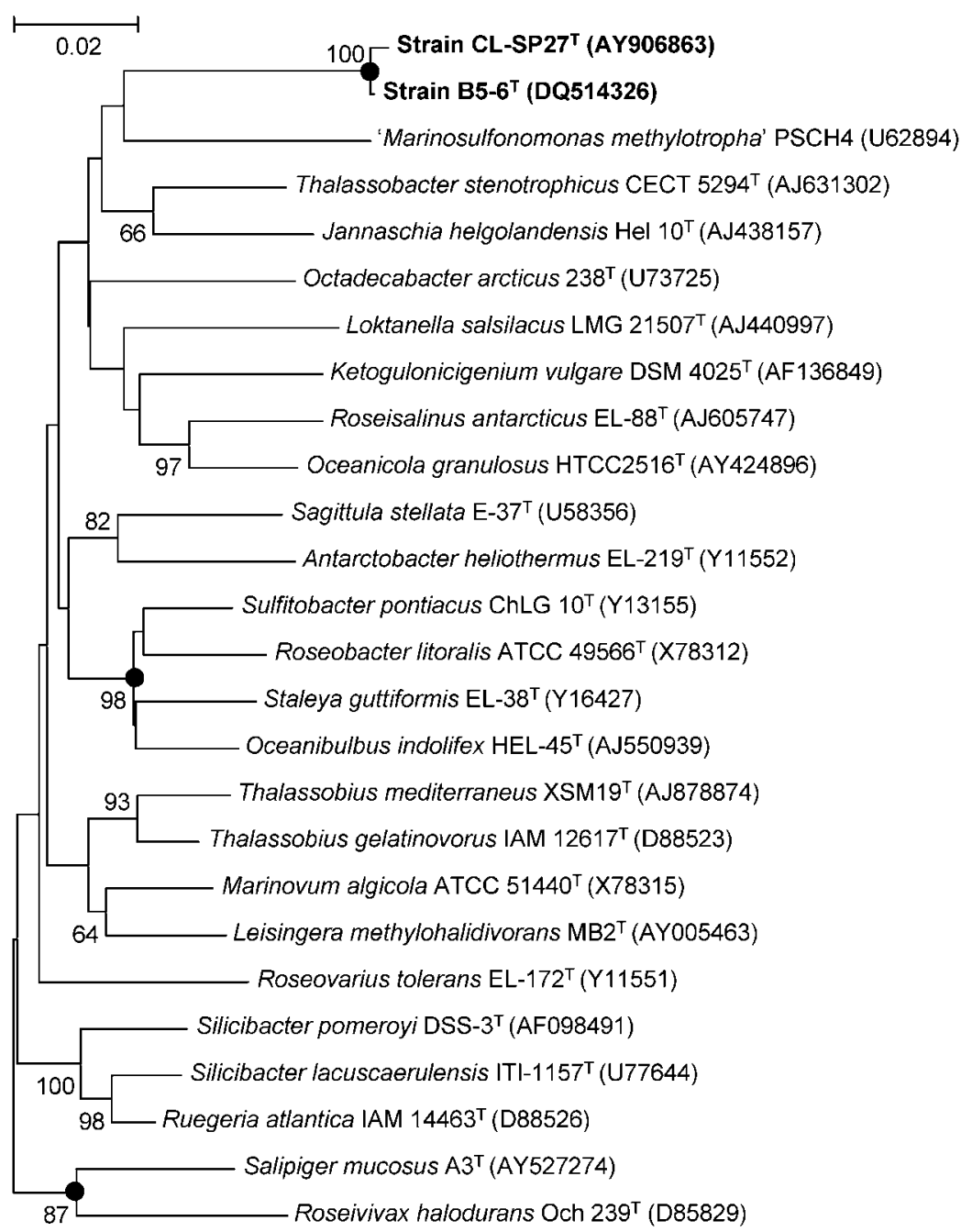

Fig. 1. Neighbour-joining tree showing relationships between strains CL-SP $27^{\top}, B 5-6^{\top}$ and other related species belonging to the Roseobacter clade of the family Rhodobacteraceae. Only bootstrap values above $60 \%$ are shown (1000 resamplings) at the branch nodes. Solid circles indicate that the corresponding nodes are also recovered in maximum-parsimony and maximum-likelihood trees. Idiomarina seosinensis (GenBank accession number AY635468) was used as the outgroup (not shown). Bar, 0.02 nucleotide substitutions per site. 
Genomic DNA-DNA relatedness was determined by dotblot hybridization. Pre-hybridization, hybridization and detection were performed using a DIG labelling and detection kit (Roche Molecular Biochemicals) according to the manufacturer's instructions. When the genomic DNA of strains CL-SP $27^{\mathrm{T}}$ and $\mathrm{B} 5-6^{\mathrm{T}}$ was used as a probe, strains B5- $6^{\mathrm{T}}$ and CL-SP $27^{\mathrm{T}}$ showed $51 \pm 2 \%$ and $46 \pm 3 \%$ DNADNA relatedness, respectively, with the reciprocal strain. Although 16S rRNA gene sequence similarity between the two novel strains was quite high $(99.6 \%)$, the DNA-DNA relatedness was lower than the level accepted as delineating species (Wayne et al., 1987). In addition, there was a considerable difference in the DNA G $+\mathrm{C}$ contents between the two novel strains $(70.0$ and $66.7 \mathrm{~mol} \%$ for strains CL$\mathrm{SP} 27^{\mathrm{T}}$ and $\mathrm{B} 5-6^{\mathrm{T}}$, respectively) as measured by HPLC according to Mesbah et al. (1989). Based on these results, the novel strains represent two separate species in a new genus within the family Rhodobacteraceae.

Morphological and physiological analyses were also performed. Morphology and motility of cells grown on MA and marine broth $2216(\mathrm{MB})$ were examined by phase-contrast microscopy. Accumulation of poly $\beta$-hydroxybutyrate (PHB) granules was determined by Nile blue A staining (Ostle \& Holt, 1982). Transmission electron microscopic investigations were performed after negative staining of cells with $2 \%$ uranyl acetate. Catalase and oxidase activities were determined according to the protocols described by Smibert \& Krieg (1994). Gelatinase, amylase, DNase, nitrate reductase activities and degradation of Tween 80 were examined as described by Hansen \& Sørheim (1991). Anaerobic growth was assessed on MA using the GasPak anaerobic system (BBL). Bacteriochlorophyll $a$ production was determined spectrophotometrically in $90 \%$ acetone extracts from cells cultured in the dark. In addition, nitrate reduction, the production of indole, arginine dihydrolase, urease, gelatinase and $\beta$-galactosidase activities, acid production from glucose and the hydrolysis of aesculin were tested using an API 20NE kit (bioMérieux). The kit was used according to the manufacturer's instructions, except that the cell suspension was prepared using artificial seawater [ASW (24 g NaCl, $5.1 \mathrm{~g} \mathrm{MgCl}_{2}, 4 \mathrm{~g} \mathrm{Na}_{2} \mathrm{SO}_{4}$, $1.1 \mathrm{~g} \mathrm{CaCl}_{2}, 0.7 \mathrm{~g} \mathrm{KCl}, 0.2 \mathrm{~g} \mathrm{NaHCO}_{3}, 0.1 \mathrm{~g} \mathrm{KBr}, 0.027 \mathrm{~g}$ $\mathrm{H}_{3} \mathrm{BO}_{3}, 0.024 \mathrm{~g} \mathrm{SrCl}_{2}, 0.003 \mathrm{~g} \mathrm{NaF}, 1 \mathrm{l}$ distilled water); Lyman \& Fleming, 1940] as a suspension medium. Other enzyme activities were also assayed using the API ZYM kit (bioMérieux) with ASW as the suspension medium. The temperature range for growth was determined on the basis of colony formation on MA plates that were incubated at $5-45{ }^{\circ} \mathrm{C}$ with increments of $5{ }^{\circ} \mathrm{C}$. The $\mathrm{pH}$ range $(\mathrm{pH} 4-12$ at intervals of $1 \mathrm{pH}$ unit) for growth was determined by changes in $\mathrm{OD}_{600}$ with time in $\mathrm{MB}$. Tolerance of sea salts was determined using synthetic ZoBell broth (distilled water ${ }^{-1}$, $5 \mathrm{~g}$ Bacto peptone, $1 \mathrm{~g}$ yeast extract, $0.1 \mathrm{~g}$ ferric citrate) at various concentrations [0 to $10 \%$ at intervals of $1 \%$ and 15 , 20 and $25 \%(w / v)$ ] of sea salts (Sigma). Ionic requirements were determined using synthetic ZoBell agar with the following combinations of salts (all w/v): (i) $3 \% \mathrm{NaCl}$; (ii)
$3 \% \mathrm{NaCl}, 0.6 \% \mathrm{MgCl}_{2} .6 \mathrm{H}_{2} \mathrm{O}$ and $0.3 \% \mathrm{MgSO}_{4} .7 \mathrm{H}_{2} \mathrm{O}$; (iii) $3 \% \mathrm{NaCl}, 0.6 \% \mathrm{MgCl}_{2} \cdot 6 \mathrm{H}_{2} \mathrm{O}, 0.3 \% \mathrm{MgSO}_{4} .7 \mathrm{H}_{2} \mathrm{O}$ and $0.06 \% \mathrm{KCl}$, and (iv) $3 \% \mathrm{NaCl}, 0.6 \% \mathrm{MgCl}_{2} \cdot 6 \mathrm{H}_{2} \mathrm{O}, 0.3 \%$ $\mathrm{MgSO}_{4} .7 \mathrm{H}_{2} \mathrm{O}, 0.06 \% \mathrm{KCl}$ and $0.2 \% \mathrm{CaCl}_{2} .2 \mathrm{H}_{2} \mathrm{O}$. Carbon utilization was tested on basal agar medium supplemented with yeast extract $(23.6 \mathrm{~g} \mathrm{NaCl}, 0.64 \mathrm{~g} \mathrm{KCl}, 4.53 \mathrm{~g}$ $\mathrm{MgCl}_{2} .6 \mathrm{H}_{2} \mathrm{O}, 5.94 \mathrm{~g} \mathrm{MgSO}_{4} .7 \mathrm{H}_{2} \mathrm{O}, 1.3 \mathrm{~g} \mathrm{CaCl}_{2} .2 \mathrm{H}_{2} \mathrm{O}$, $0.2 \mathrm{~g} \mathrm{NaNO}_{3}, 0.2 \mathrm{~g} \mathrm{NH}_{4} \mathrm{Cl}, 15 \mathrm{~g}$ Bacto agar, $0.05 \mathrm{~g}$ yeast extract, 11 distilled water; Choi et al., 2006) containing $0.2 \%$ of the carbon source. Incubation was prolonged for 1 month and growth was scored as positive when visible colonies were observed. No visible colonies were observed on control plates with no carbon source. Susceptibility to antibiotics was determined by the diffusion plate method. The following antibiotics were tested ( $\mu$ g per disc): streptomycin (10), gentamicin (10), cephalexin (30), vancomycin (30), mitomycin (1), kanamycin (30), penicillin (10), erythromycin (15), tetracycline (30), nalidixic acid (30), chloramphenicol (30), ciprofloxacin (5) and ampicillin (10).

Cells of strains CL-SP27 $7^{\mathrm{T}}$ and B5-6 ${ }^{\mathrm{T}}$ were Gram-negative, non-motile rods approximately $0.7-1.4 \times 1.0-4.5 \mu \mathrm{m}$ and $0.4-0.8 \times 1.3-2.8 \mu \mathrm{m}$, respectively. Irregular rod-forms were frequently found in both fresh and old cultures of strain CL$\mathrm{SP} 27^{\mathrm{T}}$. Elongated cells of up to $30 \mu \mathrm{m}$ were observed in old cultures. PHB granules were identified in cells of both novel strains by transmission electron microscopy (Fig. 2) and Nile blue A staining. Detailed morphological, physiological and biochemical characteristics of the strains are listed in the genus and species descriptions. The novel strains were not able to grow in medium with $\mathrm{NaCl}$ as a sole salt, but were able to grow in medium containing $\mathrm{Na}^{+}$and $\mathrm{Mg}^{2+}$. Most biochemical characteristics tested were similar between the two novel strains except glucose fermentation and esterase activity. Carbon source utilization patterns, however, were quite different between the two novel species (Table 1). Biochemical characteristics, carbon source utilization
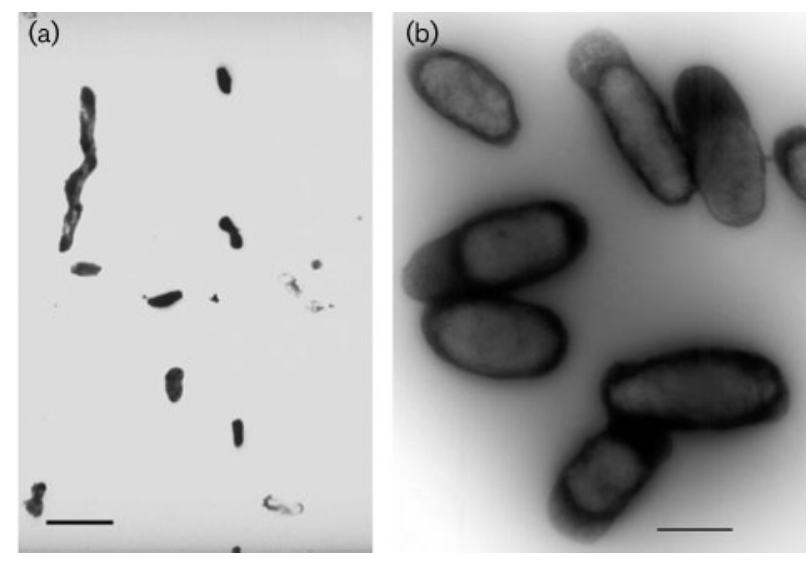

Fig. 2. Transmission electron micrographs of negatively stained cells of strains CL-SP27 $7^{\top}$ (a) and B5-6 $6^{\top}$ (b). Cells were grown at $30^{\circ} \mathrm{C}$ on MA for 5 days. Bars, (a) $2 \mu \mathrm{m}$; (b) $1 \mu \mathrm{m}$. 
Table 1. Selected characteristics that differentiate strains CL-SP27 ${ }^{\top}$ and B5-6 ${ }^{\top}$

+, Positive; -, negative; W, weakly positive; R, resistant; S, sensitive.

\begin{tabular}{|c|c|c|}
\hline Characteristic & CL-SP27 ${ }^{\mathrm{T}}$ & B5-6 ${ }^{\mathrm{T}}$ \\
\hline Origin & Hypersaline water, Korea & Seawater, Sargasso Sea \\
\hline Cell size $(\mu \mathrm{m})$ & $0.7-1.4 \times 1.0-4.5$ & $0.4-0.8 \times 1.3-2.8$ \\
\hline Glucose fermentation & - & + \\
\hline Esterase (C4) & w & + \\
\hline Temperature range $\left({ }^{\circ} \mathrm{C}\right)$ & $10-35$ & $10-40$ \\
\hline $\mathrm{pH}$ range & $7-8$ & $6-9$ \\
\hline Sea salt range $(\%)$ & $1-10$ & $2-15$ \\
\hline DNA G $+C$ content $(\mathrm{mol} \%)$ & 70.0 & 66.7 \\
\hline \multicolumn{3}{|l|}{ Sole carbon source: } \\
\hline D-Cellobiose & + & - \\
\hline Formic acid & + & - \\
\hline D-Glucose & - & + \\
\hline Glycerol & - & + \\
\hline myo-Inositol & + & - \\
\hline L-Leucine & + & - \\
\hline L-Lysine & + & - \\
\hline D-Mannitol & + & - \\
\hline L-Ornithine & + & - \\
\hline D-Raffinose & + & - \\
\hline D-Ribose & - & + \\
\hline D-Sorbitol & + & - \\
\hline Succinate & + & - \\
\hline \multicolumn{3}{|l|}{ Antibiotic susceptibility: } \\
\hline Streptomycin $(10 \mu \mathrm{g})$ & $\mathrm{R}$ & S \\
\hline
\end{tabular}

patterns and antibiotic susceptibilities can be used to differentiate the two novel strains.

Isoprenoid quinones were isolated according to Minnikin et al. (1984) and analysed by HPLC as described by Collins (1985). The major isoprenoid quinone in strains CL-SP $27^{\mathrm{T}}$ and $\mathrm{B} 5-6^{\mathrm{T}}$ is UQ-10. Fatty acid methyl esters (FAMEs) in whole cells were analysed by GC according to the instructions of the Microbial Identification System (MIDI). Dominant fatty acids for the strains were $18: 1 \omega 7 c$ (54.2-65.3\%), followed by cyclo $19: 0 \omega 8 c(8.2-21.0 \%)$ (Table 2). Strains CL-SP27 ${ }^{\mathrm{T}}$ and $\mathrm{B} 5-6^{\mathrm{T}}$ could be differentiated by the proportions of the major fatty acids (18: $1 \omega 7 c$ and cyclo $19: 0 \omega 8 c$ ) and by the presence or absence of several fatty acids, including 16:0, 17:0, $18: 3 \omega 6 c$ and 11-methyl $18: 1 \omega 7 c$ (Table 2).

In conclusion, comparative and phylogenetic analyses of $16 \mathrm{~S}$ rRNA gene sequences of the two novel strains showed they should be assigned as members of a new genus. Furthermore, morphological, biochemical and genetic characteristics clearly differentiated the novel strains from phylogenetically related species (see Supplementary Table S1 in IJSEM Online). Polyphasic evidence, such as growth ranges and carbon source utilization patterns, fatty acid profiles and DNA-DNA relatedness, demonstrated that strains CL-SP $27^{\mathrm{T}}$ and $\mathrm{B} 5-6^{\mathrm{T}}$ represent two separate novel species in the same new genus. Consequently, we propose the genus name Maribius gen. nov., containing two novel species, Maribius salinus sp. nov. (the type species) and Maribius pelagius sp. nov.

Table 2. Cellular fatty acid contents (\%) of strains CL$\mathrm{SP} 27^{\top}$ and $\mathrm{B} 5-6^{\top}$

- , Not detected. ECL, equivalent chain-length. Fatty acids that account for less than $1 \%$ of the total are not shown.

\begin{tabular}{|lcc|}
\hline Fatty acid & CL-SP27 $^{\mathbf{T}}$ & B5-6 $^{\mathbf{T}}$ \\
\hline $16: 0$ & 4.6 & - \\
$17: 0$ & 1.3 & - \\
$18: 0$ & 5.4 & 2.7 \\
$18: 3 \omega 6 c(6,9,12)$ & 1.7 & - \\
$18: 1 \omega 7 c$ & 65.3 & 54.2 \\
Cyclo $19: 0 \omega 8 c$ & 8.2 & 21.0 \\
$3-$ OH $10: 0$ & 3.5 & 3.8 \\
ECL 11.799 & 2.3 & 2.8 \\
$11-$-methyl $18: 1 \omega 7 c$ & 3.4 & - \\
$19: 1 \omega 6 c /$ ECL $18.846 / 19: 0$ cyclo $\omega 10 c$ & 1.7 & 2.4 \\
\hline
\end{tabular}




\section{Description of Maribius gen. nov.}

Maribius (Ma.ri.bi' us. L. neut. n. mare the sea; N.L. masc. n. bius from Gr. n. bios life; N.L. masc. n. Maribius sea life).

Cells are Gram-negative, non-motile rods. Growth is obligately heterotrophic and strictly aerobic. On MA medium, colonies are circular, entire, convex, opaque and beige in colour. Catalase- and oxidase-positive. Accumulate PHB granules. Require $\mathrm{Mg}^{2+}$ and $\mathrm{Na}^{+}$for growth. The predominant isoprenoid quinone is UQ-10. Dominant fatty

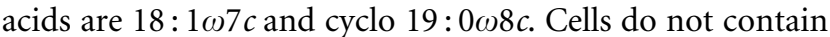
bacteriochlorophyll $a$. The $\mathrm{G}+\mathrm{C}$ content of the genomic DNA is $66.7-70.0 \mathrm{~mol} \%$. Phylogenetically, the genus is a member of the family Rhodobacteraceae. The type species is Maribius salinus.

\section{Description of Maribius salinus sp. nov.}

Maribius salinus (sa.li'nus. N.L. masc. adj. salinus salted, salty).

Displays the following properties in addition to those given in the genus description. Cells are $0.7-1.4 \mu \mathrm{m}$ wide and 1.0-4.5 $\mu \mathrm{m}$ long. Growth occurs within the temperature range of $10-35^{\circ} \mathrm{C}$ (optimum $30-35^{\circ} \mathrm{C}$ ), at $\mathrm{pH}$ values of between 7 and 8 and at sea salt concentrations of $1-10 \%$ $(\mathrm{w} / \mathrm{v})$. Gives a positive result in tests for amylase, urease, esterase (C4), esterase lipase (C8), leucine arylamidase and $\beta$-galactosidase activities and Tween 80 and aesculin hydrolysis. Negative results in tests for DNase, gelatinase, nitrate reductase, alkaline and acid phosphatase, lipase (C14), valine arylamidase, cystine arylamidase, trypsin, naphthol-AS-BI-phosphohydrolase, $\alpha$-chymotrypsin, $\alpha$ galactosidase, $\beta$-glucuronidase, $\alpha$-glucosidase, $\beta$-glucosidase, $N$-acetyl- $\beta$-glucosaminidase, $\alpha$-mannosidase, arginine dihydrolase and $\alpha$-fucosidase activities, indole production and glucose acidification. Several fatty acids, including $16: 0,17: 0,18: 0,18: 3 \omega 6 c, 3-\mathrm{OH} 10: 0$, ECL 11.799, 11methyl $18: 1 \omega 7 c$, are present at $>1 \%$. Growth occurs on citrate, D-cellobiose, D-fructose, D-mannitol, D-raffinose, D-sorbitol, D-xylose, ethanol, formic acid, L-arginine, L-leucine, L-lysine, L-ornithine, myo-inositol, $\mathrm{N}$-acetylglucosamine, pyruvic acid and succinate. No growth occurs on D-galactose, D-glucose, D-mannose, D-ribose, D-trehalose, glycerol, glycine, L-glutamate, L-proline, L-rhamnose or sucrose. The type strain is susceptible to gentamicin, cephalexin, vancomycin, mitomycin, kanamycin, penicillin, erythromycin, tetracycline, chloramphenicol, ciprofloxacin and ampicillin, but resistant to nalidixic acid and streptomycin. The DNA G $+\mathrm{C}$ content is $70.0 \mathrm{~mol} \%$.

The type strain, CL-SP27 ${ }^{\mathrm{T}} \quad\left(=\mathrm{KCCM} \quad 42113^{\mathrm{T}}=\mathrm{JCM}\right.$ $13037^{\mathrm{T}}$ ), was isolated from hypersaline water from a solar saltern in Korea.

\section{Description of Maribius pelagius sp. nov.}

Maribius pelagius (pe.la'gi.us. L. masc. adj. pelagius of or belonging to the sea).
Displays the following properties in addition to those given in the genus description. Cells are $0.4-0.8 \mu \mathrm{m}$ wide and 1.3-2.8 $\mu \mathrm{m}$ long. Growth occurs within the temperature range of $10-40{ }^{\circ} \mathrm{C}$ (optimum $30-35^{\circ} \mathrm{C}$ ), at $\mathrm{pH}$ values of between 6 and 9 and at sea salt concentrations of $2-15 \%$ $(\mathrm{w} / \mathrm{v})$. Gives a positive result in tests for amylase, urease, esterase (C4), esterase lipase (C8), leucine arylamidase, $\beta$ galactosidase activities, hydrolysis of Tween 80 and aesculin hydrolysis and glucose acidification. Negative results in tests for DNase, gelatinase, nitrate reductase, alkaline and acid phosphatases, lipase (C14), valine arylamidase, cystine arylamidase, trypsin, $\alpha$-chymotrypsin, naphthol-AS-BIphosphohydrolase, $\alpha$-galactosidase, $\beta$-glucuronidase, $\alpha$-glucosidase, $\beta$-glucosidase, $N$-acetyl- $\beta$-glucosaminidase, $\alpha$-mannosidase, $\alpha$-fucosidase and arginine dihydrolase activities and for indole production. Several fatty acids, including 18:0, 3-OH 10:0 and ECL 11.799 are present at $>1 \%$. Growth occurs on citrate, D-fructose, D-glucose, D-ribose, D-xylose, ethanol, glycerol, L-arginine, $N$-acetylglucosamine and pyruvic acid. No growth occurs on D-cellobiose, D-galactose, D-mannitol, D-mannose, D-raffinose, D-sorbitol, D-trehalose, formic acid, glycine, L-glutamate, L-leucine, L-lysine, L-ornithine, L-proline, L-rhamnose, myo-inositol, sucrose or succinate. The type strain is susceptible to gentamicin, cephalexin, vancomycin, mitomycin, kanamycin, penicillin, erythromycin, tetracycline, chloramphenicol, ciprofloxacin, ampicillin and streptomycin, but resistant to nalidixic acid. The DNA $\mathrm{G}+\mathrm{C}$ content is $66.7 \mathrm{~mol} \%$.

The type strain, B5-6 $6^{\mathrm{T}}\left(=\mathrm{KCCM} 42336^{\mathrm{T}}=\mathrm{JCM} 14009^{\mathrm{T}}\right)$, was isolated from surface water of the Sargasso Sea.

\section{Acknowledgements}

This work was supported by the Korea Sea Grant Program and the BK21 project of the Korean Government to B. C. C, the 21C Frontier program of Microbial Genomics and Applications (grant MG05-01021-0) from the Ministry of Science and Technology to J.C.C and National Science Foundation grant MCB-0237713 to S. J. G.

\section{References}

Altschul, S. F., Gish, W., Miller, W., Myers, E. W. \& Lipman, D. J. (1990). Basic local alignment search tool. J Mol Biol 215, 403-410.

Arahal, D. R., Macián, M. C., Garay, E. \& Pujalte, M. J. (2005). Thalassobius mediterraneus gen. nov., sp. nov., and reclassification of Ruegeria gelatinovorans as Thalassobius gelatinovorus comb. nov. Int J Syst Evol Microbiol 55, 2371-2376.

Buchan, A., González, J. M. \& Moran, M. A. (2005). Overview of the marine Roseobacter lineage. Appl Environ Microbiol 71, 5665-5677.

Cho, J.-C. \& Giovannoni, S. J. (2003). Parvularcula bermudensis gen. nov., sp. nov., a marine bacterium that forms a deep branch in the $\alpha$ Proteobacteria. Int J Syst Evol Microbiol 53, 1031-1036.

Choi, D. H., Kim, Y. G., Hwang, C. Y., Yi, H., Chun, J. \& Cho, B. C. (2006). Tenacibaculum litoreum sp. nov., isolated from tidal flat sediment. Int J Syst Evol Microbiol 56, 635-640.

Collins, M. D. (1985). Analysis of isoprenoid quinones. Methods Microbiol 18, 329-366. 
Felsenstein, J. (1981). Evolutionary trees from DNA sequences: a maximum likelihood approach. J Mol Evol 17, 368-376.

Fitch, W. M. (1971). Toward defining the course of evolution: minimum change for a specific tree topology. Syst Zool 20, 406-416.

Giovannoni, S. J. \& Rappé, M. (2000). Evolution, diversity and molecular ecology of marine prokaryotes. In Microbial Ecology of the Oceans, pp. 47-84. Edited by D. L. Kirchman. New York: Wiley.

Hansen, G. H. \& Sorheim, R. (1991). Improved method for phenotypical characterization of marine bacteria. J Microbiol Methods 13, 231-241.

Jeon, Y.-S., Chung, H., Park, S., Hur, I., Lee, J.-H. \& Chun, J. (2005). jPHYDIT: a JAVA-based integrated environment for molecular phylogeny of ribosomal RNA sequences. Bioinformatics 21, 3171-3173.

Jukes, T. H. \& Cantor, C. R. (1969). Evolution of protein molecules. In Mammalian Protein Metabolism, pp. 21-132. Edited by H. N. Munro. New York: Academic Press.

Kumar, S., Tamura, K. \& Nei, M. (2004). MEGA3: integrated software for molecular evolutionary genetics analysis and sequence alignment. Brief Bioinform 5, 150-163.

Lanoil, B. D., Carlson, C. A. \& Giovannoni, S. J. (2000). Bacterial chromosomal painting for in situ monitoring of cultured marine bacteria. Environ Microbiol 2, 654-665.

Lyman, J. \& Fleming, R. H. (1940). Composition of sea water. J Mar Res 3, 134-146.

Mesbah, M., Premachandran, U. \& Whitman, W. B. (1989). Precise measurement of the $\mathrm{G}+\mathrm{C}$ content of deoxyribonucleic acid by highperformance liquid chromatography. Int J Syst Bacteriol 39, 159-167.

Minnikin, D. E., O’Donnell, A. G., Goodfellow, M., Alderson, G., Athalye, M., Schaal, K. \& Parlett, J. H. (1984). An integrated procedure for the extraction of bacterial isoprenoid quinones and polar lipids. J Microbiol Methods 2, 233-241.

Ostle, A. G. \& Holt, J. G. (1982). Nile blue A as a fluorescent stain for poly- $\beta$-hydroxybutyrate. Appl Environ Microbiol 44, 238-241.

Posada, D. \& Crandall, K. A. (1998). MODELTEST: testing the model of DNA substitution. Bioinformatics 14, 817-818.

Saitou, N. \& Nei, M. (1987). The neighbor-joining method: a new method for reconstructing phylogenetic trees. Mol Biol Evol 4, 406-425.

Selje, N., Simon, M. \& Brinkhoff, T. (2004). A newly discovered Roseobacter cluster in temperate and polar oceans. Nature 427, 445-448.

Shiba, T. (1991). Roseobacter litoralis gen. nov., sp. nov., and Roseobacter denitrificans sp. nov., aerobic pink-pigmented bacteria which contain bacteriochlorophyll a. Syst Appl Microbiol 14, 140-145.

Smibert, R. M. \& Krieg, N. R. (1994). Phenotypic characterization. In Methods for General and Molecular Bacteriology, pp. 607-654. Edited by P. Gerhardt, R. G. E. Murray, W. A. Wood \& N. R. Krieg. Washington, DC: American Society for Microbiology.

Swofford, D. L. (1998). PAUP ${ }^{\star}$. Phylogenetic analysis using parsimony (*and other methods), version 4. Sunderland, MA: Sinauer Associates.

Wayne, L. G., Brenner, D. J., Colwell, R. R., Grimont, P. A. D., Kandler, O., Krichevsky, M. I., Moore, L. H., Moore, W. E. C., Murray, R. G. E. \& other authors (1987). International Committee on Systematic Bacteriology. Report of the ad hoc committee on reconciliation of approaches to bacterial systematics. Int $J$ Syst Bacteriol 37, 463-464. 